\title{
Data on geochemical and hydraulic properties of a characteristic confined/unconfined aquifer system of the younger Pleistocene in northeast Germany
}

\author{
C. Merz ${ }^{1,2}$ and J. Steidl ${ }^{1}$ \\ ${ }^{1}$ Leibniz Centre for Agricultural Landscape Research (ZALF), Institute of Landscape Hydrology, \\ Eberswalder Str. 84, 15374 Müncheberg, Germany \\ ${ }^{2}$ Freie Universität Berlin, Institute of Geological Sciences, Hydrogeology Group, \\ Malteserstr. 74-100, 12249 Berlin, Germany \\ Correspondence to: C. Merz (cmerz@zalf.de)
}

Received: 6 January 2015 - Published in Earth Syst. Sci. Data Discuss.: 27 January 2015

Revised: 6 May 2015 - Accepted: 7 May 2015 - Published: 2 June 2015

\begin{abstract}
The paper presents a database of hydrochemical and hydraulic groundwater measurements of a younger Pleistocene multilayered, unconfined/confined aquifer system in NE Germany. The Institute of Landscape Hydrology of the Leibniz Centre for Agricultural Landscape Research (ZALF) operates seven groundwater monitoring wells in the Quillow catchment located in the Uckermark region (federal state of Brandenburg, Germany). From July 2000 to March 2014, water samples were collected periodically on different days of the year and at depths between 3 and $5 \mathrm{~m}$ (shallow wells) and 16 and $24 \mathrm{~m}$ (deeper wells) below the surface. The parameters $\mathrm{pH}$ value, redox potential, electric conductivity, water temperature, oxygen content, spectral absorption coefficient and concentration of hydrogen carbonate, ammonium, phosphate, chloride, bromide, nitrite, sulfate, sodium, potassium, magnesium, calcite, dissolved organic carbon, iron(II) and manganese were determined for each sample (doi:10.4228/ZALF.2000.266). The measurements, taken over a period of 14 years, include a high variation of hydraulic situations represented by a corresponding database of 19000 recorded groundwater heads. The hydraulic head was measured between 2000 and 2014 (doi:10.4228/ZALF.2000.272).
\end{abstract}

\section{Introduction}

Groundwater quality is mainly influenced by intense reactions and processes controlled by local geologi$\mathrm{cal} /$ stratigraphic conditions and the corresponding regional hydraulic situation (Hannappel and Voigt, 1997). The environmental redox conditions in groundwater systems, for example, show a high degree of correlation with grade of aquifer coverage (Merz et al., 2009). In highly structured Pleistocene systems, anthropogenic impacts and non-steady natural conditions often lead to complex effects, the identification and quantitative assessment of which remains a challenging task (Milly et al., 2005; Germer et al., 2011; Cubasch and Kadow, 2011). Changing hydraulic boundary conditions and how they influence the observed dynamics of the subsurface water geochemistry are poorly understood (Hansen et al., 2011). The cause-effect chains of different impacts often remain unclear. A variety of issues such as decreasing groundwater levels caused by climate change, nutrient leaching due to intensive agricultural land use and groundwatersurface water interaction have to be considered (Ficklin et al., 2013; Rassam et al., 2013). For this reason, this database, including complex geochemical and hydraulic interactions, can be used for further studies regarding a 14-year period of groundwater measurements under the impact of global change.

The installation is based on a scientific monitoring program funded by the Leibniz Centre for Agricultural Landscape Research (ZALF), Müncheberg. As a complex area typical for the glacially formed Pleistocene landscapes with an agriculturally dominated land use system, the Quillow catchment (NE Germany), located some $95 \mathrm{~km}$ northeast of 


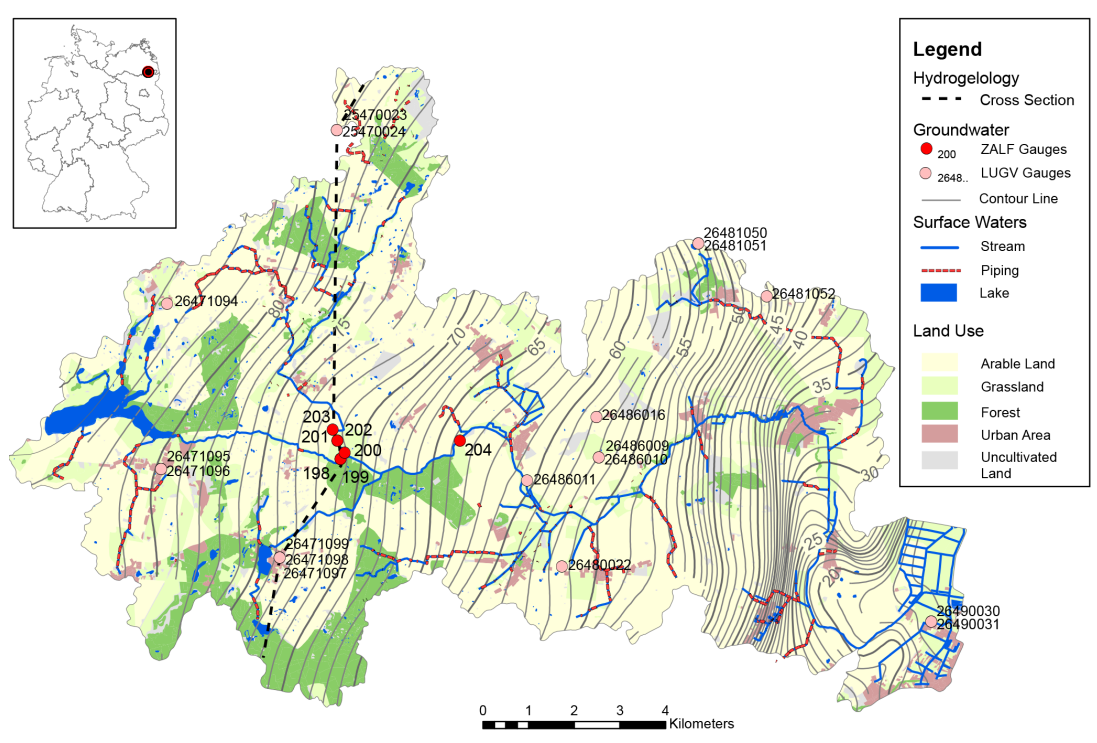

Figure 1. Shape and location of the Quillow catchment, the site of available groundwater observation wells, regional groundwater heads of the confined Weichselian-Saalian aquifer and land use/land cover over the region; transect of the regional geological profile indicated.

Berlin, was selected for this program (Fig. 1). The aim was to identify and quantify the main hydraulic and geochemical process interactions at the different interfaces in the glacial landscape and to develop a set of parameters and indicators that function as proxies for characterizing the substance dynamics in the Pleistocene aquifer systems under consideration of different land use systems. Sub-selections of this data set have already been used in a publication to identify redox conditions in aquifer systems in the federal state of Brandenburg (Merz et al., 2009), combined with data that are not yet available via open data sets.

Groundwater measurements are very rare in this region. Prior to German reunification (1989), the groundwater monitoring network was better established but focused only on hydraulic measurements. Geochemical investigations were limited to the surroundings of waterworks. None of these data have been published, and only few hydraulic data are actually available for further interpretation. Eleven groundwater wells in this region are currently being constantly hydraulically monitored by the State Office of Environment, Health and Consumer Protection (LUGV). The monitoring sites are shown in Fig. 1. Seven of these wells are also geochemically monitored (twice a year for 20 parameters: $\mathrm{EC}, \mathrm{pH}, \mathrm{O}_{2}$, anions and cations). The data sets are available from the LUGV, some of which are published in annual environmental state reports.

In the context of ZALF's scientific monitoring program, it was possible to establish seven further groundwater observation wells for the purpose of gauge monitoring and water sampling (Fig. 1). In the period from 2000 to 2014, hydrochemical parameters were measured at ZALF's hydrochemical laboratory. Two complete databases include original data for 177 groundwater analyses, with 20 measured and two calculated geochemical parameters each, and more than 19000 data concerning groundwater heads. The databases include the geochemical properties and hydraulic groundwater head variations of local unconfined and regionally confined aquifer systems in a typical younger Pleistocene water catchment of the glacial landscape in northeast Europe. The databases also include information about the geotagged location, the sample depth, filter depth and well head position in meters above sea level ( $m$ a.s.l). In this paper, we describe and discuss the data, the methodology applied and the measurement techniques involved in data collection. All parameters are available via doi:10.4228/ZALF.2000.266 and doi:10.4228/ZALF.2000.272.

\section{Materials and methods}

\subsection{Study area}

The study area, a typical younger Pleistocene catchment of the stream known as the Quillow, is located some $95 \mathrm{~km}$ northeast of Berlin, Germany (Fig. 1). An area of approximately $160 \mathrm{~km}^{2}$ is assigned as subsurface catchment in the official hydrogeological map of Brandenburg (State Office for Mining, 2012), which integrates data from the major Pleistocene aquifers. The topography of this till-dominated region is characterized by gently rolling hills, which gives the area its name - "Hummocky Landscape" (Gerke et al., 2010). Altitude decreases from $100 \mathrm{~m}$ a.s.l. in the western part of the catchment to $20 \mathrm{~m}$ a.s.l. in the southeast (glacial valley of the Ucker River). Correspondingly, regional groundwater flow is directed to the east/southeast; the Quillow is the main drainage recipient of the region (Fig. 1). Hydraulically, 


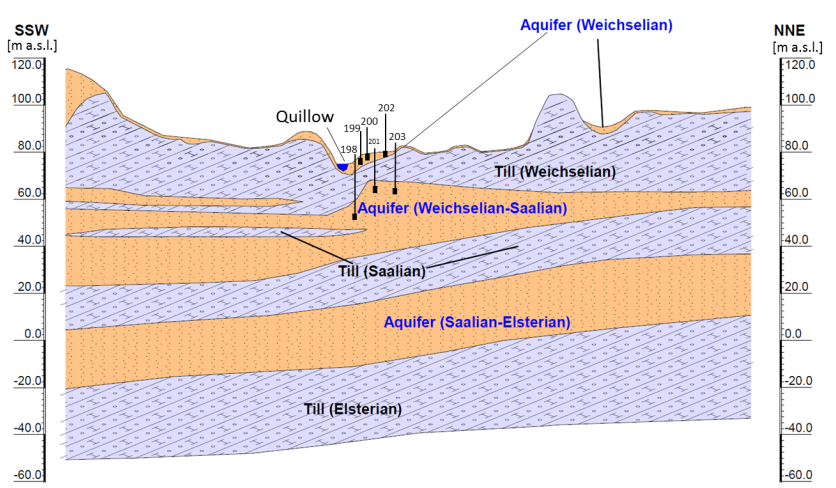

Figure 2. Regional geological profile of the Quillow catchment showing the location and depth of the ZALF's groundwater observation wells.

these regions are characterized by regional transit and local recharge dynamics of the groundwater.

The unconsolidated sediments form a series of layered Quaternary and Tertiary aquifers of about 80 to $140 \mathrm{~m}$ thickness with a $50 \mathrm{~m}$ thick Oligocene marine Rupel-clay layer as a lower confining bed. The complete series consists of permeable marine and limnic sediments of the Upper Oligocene and Miocene (thickness 5-15 m) and a complex interplay between glacial deposits of the Pleistocene with a vertical extent up to $>100 \mathrm{~m}$. These deposits, dominated by sediments from the Elster, Saalian and Weichselian glaciations, can be divided into different aquifers separated by till layers (Fig. 2). However, the thickness of the sediments varies considerably, including several subglacial trenches.

Land use in the catchment is mixed agriculture and forest, dominated by pines in the highlands and agriculture and grassland in the lowland areas (Fig. 1). Annual precipitation data collected at Dedelow meteorological station (approximately $20 \mathrm{~km}$ east) range between 490 and $640 \mathrm{~mm}$ per year, indicating a temperate to continental climate. Mean annual groundwater recharge is relatively low at approximately 70 to $90 \mathrm{~mm} \mathrm{a}^{-1}$ (Lahmer and Pfützner, 2003). The regional discharge of the Quillow ranges between 0.3 and $2.8 \mathrm{~m}^{3} \mathrm{~s}^{-1}$, which corresponds to 2 to $17 \mathrm{~L} \mathrm{~s}^{-1} \mathrm{~km}^{-2}$. A complete meteorological data set since 1991 including temperature, radiation, potential evapotranspiration and precipitation is available from the ZALF website, e.g., for 2010 under doi:10.4228/ZALF.2010.253.

\subsection{Selection and arrangement of the observation points}

Six groundwater monitoring wells were installed as a transect along the Peege stream, a tributary to the Quillow between summer 1999 and spring 2000 (Fig. 3). This location represents a typical hydrogeological situation in this complex younger Pleistocene landscape, with two aquifers separated by a 5 to $15 \mathrm{~m}$ thick till layer of Weichselian age (Fig. 2). Three wells are screened in the upper, unconfined aquifer that seasonally falls dry (gauge identifiers 199, 200 and 202) and three wells are screened in the deeper, confined aquifer (gauge identifiers 198, 201 and 203). No direct hydraulic contact was confirmed between the two aquifer systems. The transect is located approximately parallel to the regional groundwater gradient of the deeper aquifer. An additional monitoring well (gauge identifier 204) is located $3 \mathrm{~km}$ east of the transect in the flow direction of the groundwater. In the immediate vicinity of the Quillow, the upper aquifer and the till layer crop out and the deeper groundwater discharges into the stream under unconfined conditions (Fig. 4).

\subsection{Drilling methods and stratigraphy}

A drilling unit by the company NORDMEYER RSB 0/1.4 with top drive and hydraulic hammer was used to install the wells. The equipment enables $2^{\prime \prime}$ groundwater monitoring wells to be installed using a hollow drilling auger system. Before installing the wells, a complete geological log was taken using driving core soundings down to a maximum depth of $25 \mathrm{~m}$. The complete drilling profiles, including the main stratigraphic units, are shown in Fig. 4. The upper 3$4 \mathrm{~m}$ of the profile belongs to the Holocene and the youngest aquifer is of Weichselian age (Pomeranian stadial). The sediments consist of medium to coarse grained glacial sand alternating with silty-loamy layers of various thickness and lenses of weathered till. Massive grey till material of Weichselian age was found in the floor of this layer. The thickness varied between 7 and $9 \mathrm{~m}$ (wells 201 and 203) and $14 \mathrm{~m}$ at well 198 . The till is underlain by glacial fine and medium glacial sand. The upper part of this aquifer belongs to the oldest Weichselian aquifer (Brandenburger stadial); the lower part belongs to the youngest Saalian aquifer system (Warthe stadial).

The piezometers are made of high-density polyethylene with a $1-2 \mathrm{~m}$ filter screen $(0.2 \mathrm{~mm})$ installed at the deepest position of the well. The positions of well heads and screens (m a.s.l.) are shown in Table 3. The drill method requires no additional filter material to avoid the risk of clogging at the screens positioned in the permeable sandy layers. The deeper wells were sealed in a zone between the surface and the impermeable till (thickness of 3-4 m) layer using clay pellets to fill the gap between the piezometer tube (diameter $50 \mathrm{~mm}$ ) and the drilling auger system (maximum diameter $175 \mathrm{~mm}$ ). The shallow wells were sealed in the first $60-90 \mathrm{~cm}$ of the borehole. These piezometers were not installed using the hollow drilling auger system. Instead, we used the hole of the core soundings and installed the piezometers using the hydraulic hammer.

\subsection{Groundwater sampling and analytical methods}

Groundwater sampling was carried out in the field using a DANFOSS HP1 submerged pump with a pumping rate of 3$4 \mathrm{~L} \mathrm{~min}^{-1}$. Measurements of the $\mathrm{pH}$ value, redox potential, dissolved $\mathrm{O}_{2}$, conductivity and temperature were carried out 


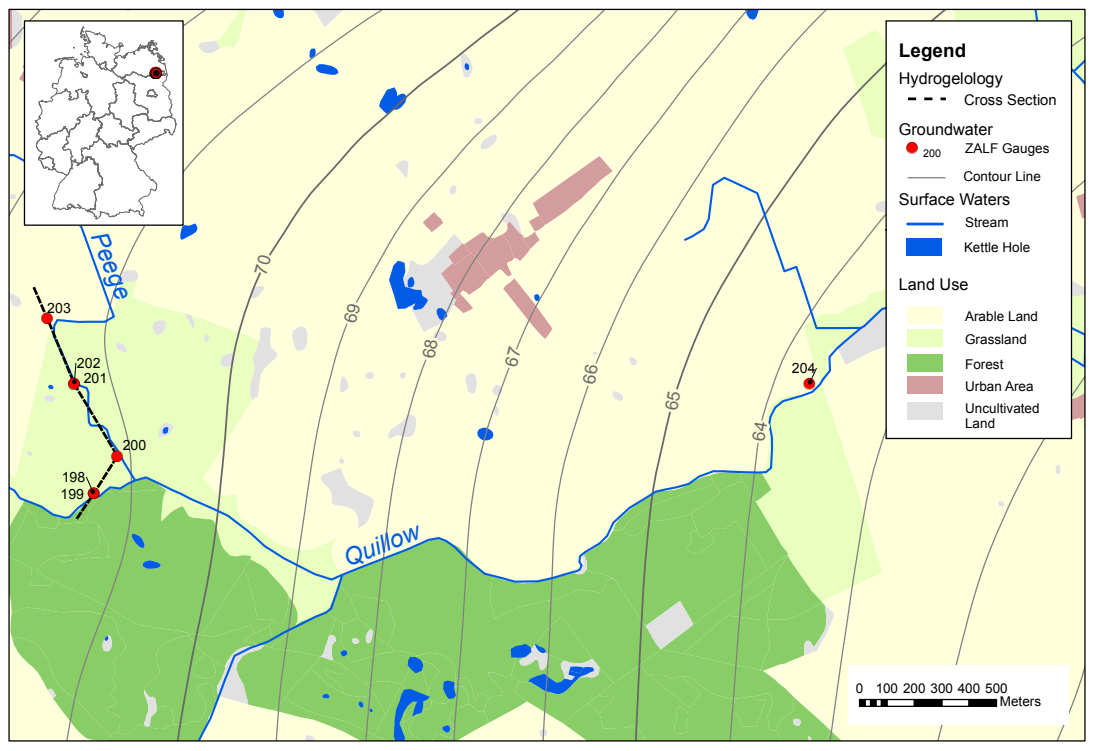

Figure 3. Location of the Quillow catchment and the site of ZALF's installed and sampled groundwater observation wells; transect of the local geological profile indicated.

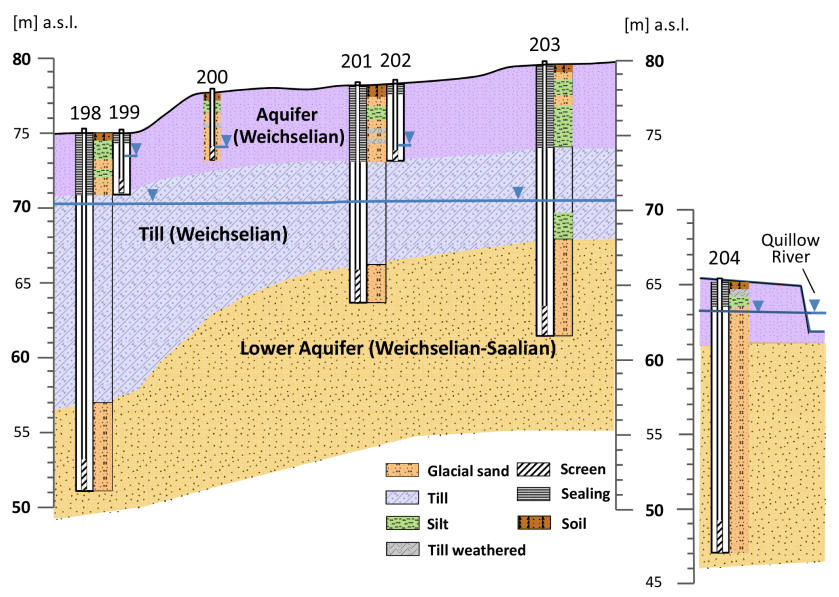

Figure 4. Hydrogeological and technical logs of each installed GW well, including the main stratigraphic units, screen positions and sealing.

in situ using a flow cell. The samples were retrieved in accordance with official DVWK guidelines (DVWK, 1992). Sampling was carried out after a minimum pumping duration of 45 min and once the geochemical parameters remained stable. The samples were filtered using $0.22 \mu \mathrm{m}$ membrane filters to exclude suspended particles, precipitations of Fe and Mn (hydr-)oxides and colloids. Samples for cation analysis were preserved using concentrated $\mathrm{HNO}_{3}$. Alkalinity samples were collected in gas-proof glass bottles and analyzed immediately in the laboratory. Full water analysis was generally performed 1 day after sampling, after the samples had been stored overnight at $4{ }^{\circ} \mathrm{C}$.
Water samples were analyzed for $\mathrm{Ca}, \mathrm{Mg}, \mathrm{K}, \mathrm{Na}, \mathrm{Cl}$, $\mathrm{NO}_{3}, \mathrm{NO}_{2}$ and $\mathrm{SO}_{4}$ by ion chromatography (METROHM IC882) using the column Metrosep C $4-250 / 4.0$ for the cations and column Metrosep A Supp $4-250 / 4.0$ for the anions. Iron and manganese were determined by ICP-AES (JOBIN YVON). Alkalinity was determined by titration using SCHOTT Titrolein 96. $\mathrm{NH}_{4}$ and $\mathrm{PO}_{4}$ were measured photometrically using a SPECORD 200, ANALYTIK JENA. Dissolved organic carbon (DOC) was determined as carbon dioxide using a SHIMADZU-TOC analyzer following catalytic oxidation. Table 1 provides a detailed overview of the database content.

\subsection{Hydraulic data}

The hydraulic conductivity of the aquifer material was not determined for this site. As part of a Master thesis, however, measurements were taken for the same stratigraphic layer (shallow aquifer: upper Weichselian aquifer, UWA; deeper aquifer: Weichselian-Saalian aquifer, WSA) a few kilometers south of the Quillow catchment using the grain size distribution analysis by Hazen and Meyer. Hydraulic permeability ranges from $5.5 \times 10^{-5}$ to $6.4 \times 10^{-4} \mathrm{~m} \mathrm{~s}^{-1}$ (UWA) and $4.0 \times 10^{-5}$ to $2.6 \times 10^{-4} \mathrm{~m} \mathrm{~s}^{-1}$ (WSA). The hydraulic conductivity of the Weichselian till was measured in the Quillow catchment by Rieckh et al. (2012), producing values between $1.9 \times 10^{-6}$ and $8.1 \times 10^{-7} \mathrm{~m} \mathrm{~s}^{-1}$. However, we expect even lower values to prevail $\left(1 \times 10^{-7} \mathrm{~m} \mathrm{~s}^{-1}\right)$.

Groundwater heads were measured using an automatic data logger system and manually using a light plummet. Wells with the deep filter screen connected to the second, confined aquifer system (gauge identifiers 198, 201, 203 and 
Table 1. Geochemical database content and structure.

\begin{tabular}{|c|c|c|c|}
\hline Column name & Parameter & Unit & Description \\
\hline TIME & & & Date \\
\hline GAUGE_ID & & & Identification of the gauge measurement \\
\hline $\mathrm{pH}$ & $\mathrm{pH}$ value & $\mathrm{mol} \mathrm{L}^{-1}$ & $\begin{array}{l}\mathrm{pH} \text { value, measurement accuracy } 0.01 \text {; WTW } \mathrm{pH} \text { meter with } \\
\mathrm{pH} \text { probe; DIN } 38404 / 5\end{array}$ \\
\hline $\mathrm{Eh}$ & Redox potential & $\mathrm{mV}$ & $\begin{array}{l}\text { Redox potential, voltage, measurement accuracy } 1 \mathrm{mV} \text {; WTW } \\
\text { pH meter with a redox single-rod measuring cell; Eh by DIN } \\
38404 / 6\end{array}$ \\
\hline $\mathrm{CON}$ & Electric conductivity & $\mu \mathrm{S} \mathrm{cm}{ }^{-1}$ & $\begin{array}{l}\text { Electric conductivity, WTW conductivity meter with probe; } \\
\text { DIN } 38404 / 8\end{array}$ \\
\hline TEMP & Water temperature & ${ }^{\circ} \mathrm{C}$ & Water temperature, measurement accuracy $0.1^{\circ} \mathrm{C}$ \\
\hline $\mathrm{O}_{2}$ & Oxygen & $\mathrm{mg} \mathrm{L}^{-1}$ & $\begin{array}{l}\text { Oxygen, measurement accuracy } 0.1 \mathrm{mg} \mathrm{L}^{-1} \text {; WTW Oxygen } \\
\text { meter; DIN } 38408 / 22+23\end{array}$ \\
\hline $\mathrm{NH}_{4}$ & Ammonium & $\operatorname{mg~L} L^{-1}$ & Ammonium, calculated from $\mathrm{NH}_{4}-\mathrm{N}$ \\
\hline $\mathrm{NH}_{4} \mathrm{~N}$ & Ammonium nitrogen & $\mathrm{mg} \mathrm{L}^{-1}$ & $\begin{array}{l}\text { Ammonium nitrogen, measured, detection limit } 0.01 \mathrm{mg} \mathrm{L}^{-1} \text {; } \\
\text { photometer SPECORD 200; } \mathrm{NH}_{4} \text { by DIN } 38406 / 5(\mathrm{Na}- \\
\text { salicylate method) }\end{array}$ \\
\hline $\mathrm{PO}_{4}$ & Soluble reactive phosphorus & $\mathrm{mg} \mathrm{L}^{-1}$ & Soluble reactive phosphorus, calculated from o- $\mathrm{PO}_{4}-\mathrm{P}$ \\
\hline $\mathrm{oPO}_{4} \mathrm{P}$ & Soluble reactive phosphorus & $\mathrm{mg} \mathrm{L}^{-1}$ & $\begin{array}{l}\text { Soluble reactive phosphorus (only phosphorus without oxygen), } \\
\text { measured, detection limit } 0.01 \mathrm{mg} \mathrm{L}^{-1} \text {; Photometer SPECORD } \\
200 ; \mathrm{PO}_{4} \text { by DIN } 38405 / 11-1 \text { (molybdate method) }\end{array}$ \\
\hline SAK & Spectral absorption coefficient & $\mathrm{m}^{-1}$ & $\begin{array}{l}\text { Spectral absorption coefficient, accuracy } 0.01 \mathrm{~nm} \text {; photometer } \\
\text { SPECORD 200; DIN 38404-3 }\end{array}$ \\
\hline Anions & & & $\begin{array}{l}\text { (METROHM IC882) with column Metrosep A Supp } 4 \text { - } \\
250 / 4.0\end{array}$ \\
\hline $\mathrm{Cl}$ & Chloride & $\mathrm{mg} \mathrm{L}^{-1}$ & Chloride, detection limit $0.03 \mathrm{mg} \mathrm{L}^{-1}$ \\
\hline $\mathrm{Br}$ & Bromite & $\mathrm{mg} \mathrm{L}^{-1}$ & Bromite, detection limit $0.03 \mathrm{mg} \mathrm{L}^{-1}$ \\
\hline $\mathrm{NO}_{2}$ & Nitrite & $\mathrm{mg} \mathrm{L}^{-1}$ & Nitrite, detection limit $0.03 \mathrm{mg} \mathrm{L}^{-1}$ \\
\hline $\mathrm{NO}_{3}$ & Nitrate & $\mathrm{mg} \mathrm{L}^{-1}$ & Nitrate, detection limit $0.03 \mathrm{mg} \mathrm{L}^{-1}$ \\
\hline $\mathrm{SO}_{4}$ & Sulfate & $\mathrm{mg} \mathrm{L}^{-1}$ & Sulfate, detection limit $0.02 \mathrm{mg} \mathrm{L}^{-1}$ \\
\hline Cations & & & (METROHM IC882) with column Metrosep C 4 - 250/4.0 \\
\hline $\mathrm{Na}$ & Sodium & $\mathrm{mg} \mathrm{L}^{-1}$ & Sodium, detection limit $0.01 \mathrm{mg} \mathrm{L}^{-1}$ \\
\hline $\mathrm{K}$ & Potassium & $\mathrm{mg} \mathrm{L}^{-1}$ & Potassium, detection limit $0.02 \mathrm{mg} \mathrm{L}^{-1}$ \\
\hline $\mathrm{Mg}$ & Magnesium & $\mathrm{mg} \mathrm{L}^{-1}$ & Magnesium, detection limit $0.02 \mathrm{mg} \mathrm{L}^{-1}$ \\
\hline $\mathrm{Ca}$ & Calcium & $\mathrm{mg} \mathrm{L}^{-1}$ & Calcium, detection limit $0.03 \mathrm{mg} \mathrm{L}^{-1}$ \\
\hline DOC & Dissolved organic carbon & $\mathrm{mg} \mathrm{L}^{-1}$ & Dissolved organic carbon, detection limit $0.05 \mathrm{mg} \mathrm{L}^{-1}$ \\
\hline $\mathrm{Fe}(\mathrm{II})$ & Iron(II) & $\mathrm{mg} \mathrm{L}^{-1}$ & $\begin{array}{l}\text { Iron(II) } \mathrm{Fe}^{2+} \text {, detection limit } 0.03 \mathrm{mg} \mathrm{L}^{-1} \text {; } \\
\text { ICP-AES with atomizer; optical emission spectroscopy }\end{array}$ \\
\hline $\mathrm{Mn}$ & Manganese & $\mathrm{mg} \mathrm{L}^{-1}$ & $\begin{array}{l}\text { Manganese, detection limit } 0.05 \mathrm{mg} \mathrm{L}^{-1} \text {; ICP-AES with atom- } \\
\text { izer; optical emission spectroscopy }\end{array}$ \\
\hline $\mathrm{HCO}_{3}$ & Hydrogen carbonate & $\mathrm{mmol} \mathrm{L}^{-1}$ & $\begin{array}{l}\text { Hydrogen carbonate, accuracy } 0.01 \mathrm{mmol} \mathrm{L}^{-1} \text {; titration with } \\
\text { SCHOTT Titroline } 96\end{array}$ \\
\hline
\end{tabular}

204) were equipped with an automatic data logger system by Ackermann KG (Berlin). The logger measured the GW head every day. The data logger was calibrated on the basis of regular manual measurements. The groundwater heads of the shallow wells connected to the first, unconfined aquifer were measured manually every 4 weeks using a light plummet (gauge identifiers 199, 200 and 202). Due to the high variation of water levels in the case of prolonged dry periods, an automatic logger system was unsuitable in these wells. Table 2 provides an overview of the database content.

\section{Discussion}

The hydrogeological structure in the Uckermark region is very complex. Hydrologically, this region belongs to a transit unit of the Pleistocene landscape. In glacially formed Pleistocene landscapes, transit regions are characterized by regional aquifers, which are largely covered by thick layers of till. These aquifers of Weichselian-Saalian age are characterized by relatively low hydraulic gradients, low flow velocities and confined hydraulic conditions (for a regional 
Table 2. Hydraulic database content and structure.

\begin{tabular}{llll}
\hline Column name & Parameter & Unit & Description \\
\hline $\begin{array}{l}\text { TIME } \\
\text { GAUGE_ID } \\
\text { WPN }\end{array}$ & Groundwater head & $\mathrm{m}$ (a.s.l.) & $\begin{array}{l}\text { Date } \\
\text { Identification of the gauge measurement } \\
\text { Groundwater level below surface, measurement accuracy 1 mm; } \\
\text { automatic data logger ACKERMANN KG (Berlin, Germany) }\end{array}$ \\
WPN & Groundwater head & $\mathrm{m}$ (a.s.l.) & $\begin{array}{l}\text { Groundwater level below surface, measurement accuracy 1 mm; } \\
\text { measurement with light plummet }\end{array}$ \\
\hline
\end{tabular}

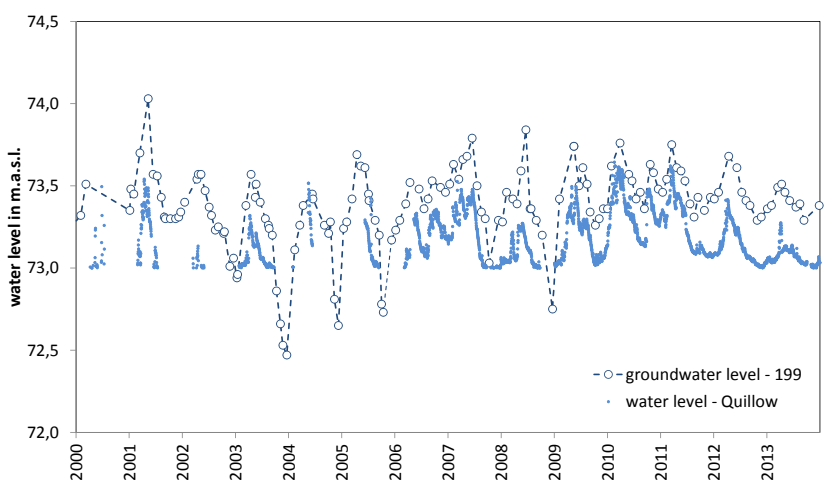

Figure 5. Comparison of surface water levels of the Quillow and groundwater heads of the unconfined upper aquifer at gauge position 199.

cross-section, see Fig. 2). Local groundwater recharge plays only a minor role in the regional water budget. Local, unconfined and only temporarily saturated aquifers of Weichselian age (Pomeranian stadial) are deposited above the till layers. Due to the short distance to the groundwater table and the missing till layer, local aquifers are vulnerable to nutrient input by agricultural land use (Böhlke et al., 2002). The geochemical environment of this groundwater is characterized by high oxygen contents with low DOC concentrations $\left(<3 \mathrm{mg} \mathrm{L}^{-1}\right)$. The oxygen content reaches nearly saturation level. The redox potential of $>250 \mathrm{mV}$ and trace element concentrations below the detection limits are distinct indicators of stable aerobe conditions. The nitrate concentration in this aquifer varied between 20 and $60 \mathrm{mg} \mathrm{L}^{-1}$ over the whole monitored period. Budget calculations by Wurbs et al. (2000) revealed that the nitrate concentration in sandy, aerobe and uncovered pleistocene aquifers was controlled exclusively by the quantity of $\mathrm{N}$ surplus from the agricultural management system. The in situ denitrification process plays no quantitative role (Kersebaum, 2000). Hydraulically, these local shallow aquifers are connected relatively quickly to the smaller surface water system and, therefore, when they are hydrous they are mainly responsible for the relatively high nutrient load of the surface water system (Behrendt and Dannowski, 2005; Bachor et al., 2012). However, nitrate concentration is not a good indicator of the influence of land use alone. In this region, the stream water nitrate concentration
Table 3. The coordinates of well heads and positions of screens.

\begin{tabular}{lllll}
\hline Gauge_ID & $X$-coordinate & $Y$-coordinate & $\begin{array}{l}\text { WPN } \\
\mathrm{m}(\text { a.s.1.) }\end{array}$ & $\begin{array}{l}\text { Depth of screen } \\
\mathrm{m} \text { (a.s.1.) }\end{array}$ \\
\hline 198 & 3409934 & 5912302 & 75.27 & $51.27-53.27$ \\
199 & 3409934 & 5912302 & 75.76 & $72.20-71.20$ \\
200 & 3410020 & 5912439 & 78.1 & $74.10-73.10$ \\
201 & 3409863 & 5912702 & 78.29 & $65.79-63.79$ \\
202 & 3409863 & 5912702 & 77.8 & $74.14-73.14$ \\
203 & 3409764 & 5912942 & 79.46 & $63.46-61.46$ \\
204 & 3412546 & 5912702 & 65 & $49-47$ \\
\hline
\end{tabular}

depends also on the contribution of deeper anoxic groundwater with high denitrification capacity. Downstream of the catchment, these aquifers are connected to the surface water system via base flow; nutrient input quantities by deep groundwater plays only a minor role (Merz et al., 2009).

Data show that regional stream water levels exhibited long-term trends that were approximately synchronous with groundwater levels of the upper aquifer (Fig. 5). As a result, the lower the groundwater head, the less the quality of stream water seemed to be impacted by agriculture. Here, the periodical drying out of the upstream was associated with low groundwater levels. During these periods, parts of the vadose zone in the upstream of the catchment were hydraulically decoupled from the streams.

The underlying deeper aquifer systems in this region are well protected from diffuse nitrate and oxygen inputs by the till cover. Due to a lack of oxygen, a stable anaerobic environment can be observed. Nutrient concentrations in the groundwater were low during the monitored period. Groundwater analyses in the aforementioned regions reveal stable anaerobe geochemical conditions, indicating a progressive Fe reduction. Due to the limited delivery of electron donators under strictly confined conditions, however, the redox state is limited to a relatively labile ferrous-ferric equilibrium in the deeper aquifer.

The confined groundwater exhibits very low nitrate concentrations; a very effective denitrification rate can be expected under the dominating redox conditions. Over the last 10 years, however, the data show a steadily increasing tendency for more oxic conditions and thus a decrease in denitrification capacity in the deeper aquifers at the sites under investigation. This clear trend is not directly related to ground- 
water head. Although the pressure heads in the deeper aquifer constantly decreased from 2001 to 2008 , an increase of the groundwater heads could be detected from 2008 to 2012 . From 2012 to 2014 the pressure heads remain constant. The oxidation process is based on increasing $\mathrm{SO}_{4}$ and decreasing $\mathrm{Fe}(\mathrm{II})$ concentrations. We propose a slow but constant diffusion of oxygen and nitrate into the deeper aquifer system. Regarding the long-term process of denitrification, however, a continuous input of nitrate can destroy the reduction capacity of the aquifer. Due to the limited subsequent delivery of organic material, electron exchange can act as a limiting factor, and autotrophic denitrification with pyrite reacting as an electron donator is unable to compensate for this.

\section{Conclusions}

Although the long-term measurement of the geochemical and hydraulic parameters of groundwater properties is costly and time-consuming, it is necessary in order to gain a deeper understanding of how the hydrological system works under changing boundary conditions. This database, including complex geochemical and hydraulic information, can therefore be used for further investigations regarding a 14-year period of groundwater data under changing conditions. The results ought to provide complex knowledge for evaluating and adapting land and water management for glacial landscapes in the Northern Hemisphere under the pressure of global change.

\section{Data access}

The data used for geochemical analysis are published under doi:10.4228/ZALF.2000.266. This data set contains 177 geochemical analyses of groundwater samples covering a wide range of environmental redox conditions. The data concerning the corresponding hydraulic conditions are published under doi:10.4228/ZALF.2000.272. This data set contains measured groundwater heads of two aquifers with different temporal resolutions (1 day to 4 weeks).

Acknowledgements. We would like to thank J. Pilz and R. Schmitt from ZALF's Department of Landscape Information Systems for their great assistance.

Edited by: A. Demény

\section{References}

Bachor, A., Nawrocki, A., and Evert, J.: Schadstoffuntersuchungen in Oberflächengewässern Mecklenburg-Vorpommerns im Zeitraum 2007-2011, Schadstoffe zur Bewertung des chemischen Zustands gemäß Oberflächengewässerverordnung (OGewV), Herausgeber: Landesamt für Umwelt, Naturschutz und Geologie Mecklenburg-Vorpommern, 77 pp., ISSN: 18604072, 2012.

Behrendt, H. and Dannowski, R. (Eds.): Nutrients and heavy metals in the Odra river system - Emissions from point and diffuse sources, their loads, and scenario calculations on possible changes, Weißensee Verlag Berlin, 353 pp., 2005.

Böhlke, J. K., Wanty, R., Tuttle, M., Delin, G., and Landon, M.: Denitrification in the recharge area and discharge area of a transient agricultural nitrate plume in a glacial outwash and aquifer, Minnesota, Water Resour. Res., 38, 1-26, 2002.

Cubasch, U. and Kadow, C.: Global climate change and aspects of regional climate change in the Berlin-Brandenburg region, Erde, 142, 3-20, 2011.

DVWK: Grundwasseruntersuchung und Probenahme 128, Regeln zur Wasserwirtschaft-Entnahme und Untersuchungsumfang von Grundwasserproben, 36 pp., 1992.

Ficklin, D. L., Luo, Y. Z., and Zhang, M. H.: Watershed modelling of hydrology and water quality in the Sacramento River watershed, California, Hydrol. Process., 27, 236-250, 2013.

Gerke, H. H., Koszinski, S., Kalettka, T., and Sommer, M.: Structures and hydrologic function of soil landscapes with kettle holes using an integrated hydropedological approach, J. Hydrol., 393, 123-132, 2010.

Germer, S., Kaiser, K., Oliver, B., and Huettl, R. F.: Water balance changes and responses of ecosystems and society in the BerlinBrandenburg region - a review, Erde, 147, 65-95, 2011.

Hannappel, S. and Voigt, H.-J.: Beschaffenheitsmuster des Grundwassers im Lockergestein, Umweltgeochemie, edited by: Matschullat, J., Tobschall, H., and Voigt, H.-J., Springer, Heidelberg, 360-393, 1997.

Hansen, D. J., McGuire, J. T., and Mohanty, B. P.: Enhanced biogeochemical cycling and subsequent reduction of hydraulic conductivity associated with soil-layer interfaces in the vadose zone, J. Environ. Qual., 40, 1941-1954, 2011.

Kersebaum, K. C.: Model based evaluation of land use and management strategies in a nitrate polluted drinking water catchment in North-Germany, in: Integrated Watershed Management in the Global Environment, edited by: Lal, R., CRC Press, Boca Raton, 223-238, 2000.

Lahmer, W. and Pfützner, B.: Orts- und zeitdiskrete Ermittlung der Sickerwassermenge im Land Brandenburg auf der Basis flächendeckender Wasserhaushaltsberechnungen. PIK-Report 85. Potsdam-Institut für Klimafolgenforschung, Potsdam, 2003.

Merz, C., Steidl, J., and Dannowski, R.: Parameterization and regionalization of redox based denitrification for GIS-embedded nitrate transport modeling in Pleistocene aquifer systems, Environ. Geol., 58, 1587-1599, 2009.

Milly, P. C. D., Dunne, K. A., and Vecchia, A. V.: Global pattern of trends in streamflow and water availability in a changing climate, Nature, 438, 347-350, 2005.

Rassam, D. W., Peeters, L., Pickett, T., Jolly, I., and Holz, L.: Accounting for surface groundwater interactions and their uncer- 
tainty in river and groundwater models: a case study in the Namoi River, Australia, Environ. Model. Softw., 50, 108-119, 2013.

Rieckh, H., Gerke, H. H., and Sommer, M.: Hydraulic properties of characteristic horizons depending on relief position and structure in a hummocky glacial soil landscape, Soil Till. Res., 125, 123$131,2012$.
Wurbs, A., Kersebaum, K. C., and Merz, C.: Quantification of leached pollutants into the groundwater caused by agricultural land use - Scenarios as a method for quantitative risk assessment of groundwater pollution, in: Integrated Watershed Management in the Global Environment, edited by: Lal, R., CRC Press, Boca Raton, 239-250, 2000. 